\title{
Opodatkowanie dochodu ze sprzedaży nieruchomości dokonanej poza działalnością gospodarczą w świetle przepisów ustawy o podatku dochodowym od osób fizycznych
}

\section{Wprowadzenie}

Celowość podjęcia analizy problematyki opodatkowania odpłatnego zbycia nieruchomości podatkiem dochodowym od osób fizycznych $^{1}$ jest uzasadniona $z$ dwóch co najmniej powodów. Po pierwsze składniki majątku nieruchomego bardzo często przedstawiają znaczną wartość materialną i w związku z tym kwestia opodatkowania wartości uzyskiwanych $z$ tytułu ich obrotu jest doniosła. Dla podatnika nie będzie nigdy rzeczą obojętną, czy i w jakiej wysokości zostanie mu wymierzony podatek dochodowy $z$ tytułu dokonywania sprzedaży dóbr nieruchomych. Drugą, bardziej istotną kwestią jest fakt, że w ostatnich latach przepisy regulujące zasady opodatkowania odpłatnego zbycia nieruchomości podlegały częstym i dość daleko idącym zmianom. W dodatku na mocy wprowadzonych przez ustawodawcę przepisów intertemporalnych część niegdyś obowiązującej regulacji w dalszym ciągu pozostaje w pewnym zakresie aktualna. $Z$ tego właśnie względu pochylenie się nad przedmio-

\footnotetext{
${ }^{1}$ Zob. także S. Brzeszczyńska, Odpłatne zbycie nieruchomości na rynku transakcji prywatnych, Monitor Podatkowy 2009, nr 6, s. 11-18.
} 
tową problematyką nie może ograniczać się jedynie do analizy ówcześnie obowiązujących przepisów. Konieczne zatem staje się spojrzenie na prezentowaną materię z szerszej, w ujęciu czasowym, perspektywy, a więc $z$ uwzględnieniem stanu prawnego obowiązującego jeszcze przed 1 stycznia 2007 r., kiedy to weszły w życie pierwsze najistotniejsze zmiany odnośnie do prezentowanej problematyki.

Podejmując się opracowania najważniejszych aspektów opodatkowania dochodów uzyskanych ze sprzedaży nieruchomości, po pierwsze należy wskazać na ratio legis takiego działania ustawodawcy. Celem niniejszej pracy będzie również scharakteryzowanie przychodów $z$ odpłatnego zbycia nieruchomości jako odrębnego źródła przychodu. W dalszej części opracowania swoją uwagę skupię na przedstawieniu zasad dotyczących opodatkowania dochodów ze sprzedaży nieruchomości w świetle dokonywanych w ostatnich latach nowelizacji. Wreszcie na zakończenie skoncentruję się na problematyce ulg i zwolnień podatkowych związanych z tym właśnie źródłem przychodu.

\section{Ratio legis opodatkowania umów sprzedaży nieruchomości podatkiem dochodowym}

Jak zgodnie wskazuje się w literaturze i orzecznictwie ${ }^{2}$, podstawowym założeniem, które przyświecało ustawodawcy podatkowemu przy nakładaniu podatku z tytułu dochodów osiąganych w związku ze zbyciem składników majątku nieruchomego, była chęć wyeliminowania zjawiska spekulacji na rynku nieruchomości. Nietrudno zauważyć, że takie praktyki należy uznać a priori za społecznie niepożądane. Można więc sformułować uzasadnioną hipotezę, że opodatkowując tak uzyskany przychód, ustawodawca, oprócz dążenia do realizacji fiskalnych celów państwa, uzewnętrznił swe dążenie do wypełnienia także innych niż fiskalne założeń. W tym

2 Por. A. Bartosiewicz, R. Kubacki, Ustawa o podatku dochodowym od osób fizycznych: komentarz, Warszawa 2005, s. 349; wyrok NSA z 9.04.2002 r., III SA 2717/00. 
wypadku przejawiają się one w dążeniu do eliminacji społecznie niepożądanego zjawiska.

Drugą kwestią, na którą należy zwrócić uwagę, jest fakt, że opodatkowanie odpłatnego zbycia nieruchomości służyć miało przeciwdziałaniu sytuacji unikania opodatkowania przez osoby stale trudniące się odsprzedażą z zyskiem i w ten sposób zapewniające sobie stałe źródło dochodów z tytułu dokonywanego obrotu majątkiem nieruchomym. Coraz częściej podkreśla się jednak, że argument ten w chwili obecnej mocno stracił na znaczeniu. Współcześnie bowiem zdaje się dominować pogląd o zaliczaniu tego typu praktyk do przychodów $z$ faktycznie prowadzonej działalności gospodarczej, i to bez względu na okoliczność, czy jest ona wykonywana w ramach formalnie zgłoszonej działalności ${ }^{3}$.

$Z$ tego powodu coraz częściej pojawiają się głosy o braku zasadności uznania odpłatnego zbycia nieruchomości i innych praw majątkowych za odrębne źródło przychodu ${ }^{4}$. Stanowisko to staje się jeszcze bardziej uzasadnione, jeżeli spojrzy się na szeroki wachlarz przewidzianych przez ustawodawcę zwolnień podatkowych w tym zakresie.

$Z$ drugiej jednak strony częste nowelizacje analizowanej problematyki mogą świadczyć, że ustawodawca nie zamierza w sposób definitywny rezygnować $z$ opodatkowania przychodów ze sprzedaży nieruchomości, a chociażby obserwowany znaczny wzrost cen mieszkań - i to zarówno na rynku pierwotnym, jak i wtórnym w latach 2006-2008 zdaje się potwierdzać zasadność utrzymania tego rodzaju opodatkowania.

\section{Opodatkowanie odpłatnego zbycia nieruchomości jako odrębne źródło przychodów}

Ustawodawca w ustawie o podatku dochodowym od osób fizycznych dokonuje wyszczególnienia wszelkich uzyskiwanych przez podatnika przychodów do poszczególnych ich kategorii. W świetle

\footnotetext{
3 Zob. A. Bartosiewicz, R. Kubacki, op.cit., s. 349.

4 Ibidem.
} 
regulacji art. 10 ust. 1 pkt 8 lit. a ustawy o podatku dochodowym od osób fizycznych ${ }^{5}$ odrębnym źródłem przychodów, przy jednoczesnym spełnieniu dodatkowych warunków, jest odpłatne zbycie nieruchomości lub ich części, w tym udziału w nieruchomości. Powyższe oznacza, że zawarcie przez podatnika umowy sprzedaży nieruchomości co do zasady będzie skutkowało powstaniem po jego stronie przychodu podlegającego opodatkowaniu podatkiem dochodowym od osób fizycznych.

Pierwszą uwagą, jaka nasuwa się w kontekście omawianej problematyki, jest okoliczność, że ustawodawca reguluje problematykę odpłatnego zbycia nieruchomości dwutorowo. Konsekwencją takiego stanu rzeczy jest konieczność uwypuklenia podatkowoprawnego zróżnicowania tych przychodów $z$ tytułu sprzedaży nieruchomości, które osiągnięte zostały w związku z prowadzoną przez dany podmiot działalnością gospodarczą, od pozostałych przychodów $z$ odpłatnego zbycia, lecz niezwiązanych $z$ działalnością profesjonalną podatnika. Do takiego wniosku wiedzie rezultat wykładni językowej art. 10 ust. 1 pkt 8 u.p.d.o.f. $Z$ przytoczonego przepisu wynika, że niezbędnym warunkiem uprawniającym do zakwalifikowania wartości uzyskiwanych $z$ tytułu sprzedaży składników majątku nieruchomego jako przychodów $\mathrm{z}$ odpłatnego zbycia jest brak związku transakcji, w wyniku której powstaje wspomniany przychód, $z$ faktem prowadzenia przez podatnika działalności gospodarczej. W przeciwnym razie uzyskane przez podatnika wartości zaliczane będą co do zasady do przychodów z pozarolniczej działalności gospodarczej, o której mowa w art. 10 ust. 1 pkt 3 u.p.d.o.f. Dlatego niezbędnym warunkiem, aby można było mówić o odrębnym źródle przychodu w postaci odpłatnego zbycia nieruchomości, o którym czytamy w art. 10 ust. 1 pkt 8 ustawy, jest konieczność osiągnięcia przychodu z tego tytułu poza działalnością profesjonalną. W konsekwencji przywołany przepis znajdzie zastosowanie wyłącznie wówczas, gdy podatnik nie prowadzi działalności gospodarczej w ogóle lub też gdy działalność taką co prawda

${ }^{5}$ Ustawa z dnia 26 lipca 1991 roku o podatku dochodowym od osób fizycznych (tj. Dz.U. z 2000 r. Nr 14, poz. 176 ze zm.) przywoływana będzie dalej jako u.p.d.o.f. 
prowadzi, lecz jej przedmiotem nie jest dokonywanie transakcji sprzedaży nieruchomości.

Należy zaznaczyć, że przepisu art. 10 ust. 1 pkt 8 nie stosuje się do tych transakcji zbycia składników majątku nieruchomego, które są powiązane $z$ prowadzoną przez podatnika działalnością gospodarczą niepolegającą na sprzedaży nieruchomości. Nie będą również stanowić przychodu $z$ omawianego źródła wartości uzyskane ze zbycia składników, o których mowa, wycofanych uprzednio $z$ tej działalności. Nie oznacza to jednak, że tak uzyskane wartości nie będą w ogóle podlegać opodatkowaniu. W takiej sytuacji odpłatne zbycie składników majątku wykorzystywanych na potrzeby związane $z$ działalnością gospodarczą traktowane jest jako przychód z pozarolniczej działalności gospodarczej. Wyjątkiem od tej zasady jest natomiast sytuacja, gdy okres między ich zbyciem a pierwszym dniem miesiąca następującym po miesiącu, w którym składniki majątku zostały wycofane, wyniósł co najmniej 6 lat. W tym przypadku uzyskany przychód w ogóle nie będzie podlegał opodatkowaniu.

Jak już zostało zasygnalizowane na początku, sprzedaż nieruchomości rodzić będzie określone skutki podatkowe tylko wtedy, gdy zostaną spełnione pewne dodatkowe warunki. W szczególności ustawodawca wymaga, aby odpłatne zbycie składników majątku nieruchomego dokonane zostało w określonym czasie, czyli przed upływem 5 lat, licząc od końca roku kalendarzowego, w którym nastąpiło nabycie lub wybudowanie nieruchomości. W przeciwnym razie wartości uzyskiwane $z$ tytułu ich sprzedaży nie będą stanowiły przychodu w rozumieniu art. 10 ust. 1 pkt 8 u.p.d.o.f. i wobec tego nie będą podlegały opodatkowaniu podatkiem dochodowym.

Ponieważ ustawodawca podatkowy nie definiuje znaczenia użytych terminów „nabycie” oraz „wybudowanie”, w praktyce stosowania prawa pojawiły się wątpliwości interpretacyjne na tle ustalenia ich prawidłowego zakresu znaczeniowego.

Najwięcej kontrowersji wzbudzało przeprowadzenie właściwej wykładni terminu „nabycie”. Zgodnie $z$ utrwalonym stanowiskiem judykatury, dokonując wykładni językowej przepisów prawa podatkowego, należy zawsze brać najpierw znaczenie użytych słów w rozumieniu powszechnie przyjętym w języku polskim, chyba że 
ustawodawca nada tym słowom w prawie podatkowym specyficzną treść, odmienną od języka potocznego ${ }^{6}$. W języku potocznym natomiast termin „nabycie” oznacza tyle, co otrzymać coś na własność, płacąc za to, oraz zyskać coś lub zdobyć. Tak sformułowana definicja nabycia jest jednak bardzo szeroka. W tej sytuacji pomocne mogłoby się okazać odwołanie do znaczenia prezentowanego pojęcia w prawie cywilnym. I tak w cywilistyce zasadne jest wprowadzenie rozróżnienia pomiędzy nabyciem pierwotnym a nabyciem pochodnym. W pierwszym przypadku, którego egzemplifikacją jest uzyskanie własności rzeczy lub innych praw majątkowych w drodze zasiedzenia, nabywca nie wywodzi swych praw do rzeczy od innej osoby. Odwrotnie sytuacja przedstawia się natomiast w przypadku nabycia pochodnego, które charakteryzuje się właśnie tym, że nabywca swoje prawa wywodzi od zbywcy. Jak stwierdził Sąd Najwyższy, terminem „nabycie”, użytym w omawianym przepisie, należy posługiwać się bez żadnych ograniczeń, wobec czego odnosi się ono zarówno do nabycia pochodnego, jak i pierwotnego ${ }^{7}$.

Jednakże, jak się szybko okazało, tak szerokie rozumienie terminu „nabycie” wiodło w wielu wypadkach do nienadających się do zaakceptowania skutków. W pewnych uzasadnionych przypadkach zakres znaczeniowy nabycia był więc sukcesywnie ograniczany w judykaturze. W szczególności nie stanowi nabycia nieruchomości w świetle analizowanego przepisu zwrot nieruchomości dokonany na podstawie art. 69 ust. 1 nieobowiązującej już ustawy z dnia 29 kwietnia 1985 r. o gospodarce gruntami i wywłaszczaniu nieruchomości. Uzasadnieniem tego stanowiska jest fakt, że tak dokonany zwrot stanowi jedynie przeprowadzoną na mocy decyzji administracyjnej restytucję, skutkującą przywróceniem stosunków prawnorzeczowych do stanu sprzed wywłaszczenia ${ }^{8}$. Identycznie sytuacja przedstawia się, gdy zwrot wywłaszczonej nieruchomości nastąpił na rzecz spadkobiercy 9 .

\footnotetext{
6 Wyrok NSA z 23.04.1998 r., I SA/Po 1792/97.

7 Wyrok SN z 6.08.1999 r., III RN 33/99.

8 Wyrok SN z 7.05.2002 r., III RN 18/02.

9 Wyrok WSA w Bydgoszczy z 17.10.2006 r., I SA /Bd 503/06.
} 
Za nabycie nie uważa się także takiego zdarzenia prawnego, które polega na przyznaniu własności rzeczy w drodze zniesienia współwłasności, działu spadku czy podziału majątku wspólnego ${ }^{10}$. Nie jest również nabyciem nieruchomości przez drugiego małżonka włączenie jej do majątku wspólnego małżonków w drodze umowy rozszerzającej ustawową wspólność majątkową ${ }^{11}$.

Oprócz ustalenia prawidłowego znaczenia terminu „nabycie” istotna jest dla analizowanego przepisu wykładnia terminu „wybudowanie”. W najnowszym orzecznictwie nie kwestionuje się już poglądu o konieczności przyjęcia potocznego, słownikowego jego rozumienia, co oznacza, że nie zachodzą żadne uzasadnione przesłanki wskazujące na potrzebę posiłkowania się definicjami, przepisami bądź instytucjami wypracowanymi przez inne gałęzie prawa.

Podkreślenia wymaga fakt, że tak sformułowana teza pociąga za sobą doniosłe konsekwencje praktyczne. Niegdyś bowiem organy podatkowe stały na stanowisku, że budynek można uznać za wybudowany dopiero wówczas, gdy spełnione zostały wszystkie formalności wynikające $z$ prawa budowlanego. Było to stanowisko niekorzystne dla podatników z uwagi na okoliczność, że uzyskanie ostatecznej decyzji o pozwoleniu na użytkowanie budynku było często procesem długotrwałym. W ten sposób organy podatkowe odwlekały początek biegu 5-letniego terminu, po upływie którego podatnik był wolny od ciążącego na nim zobowiązania podatkowego, co powodowało, że wspomniany termin de facto ulegał wydłużeniu ${ }^{12}$. Naczelny Sąd Administracyjny przesądził jednak, że w procesie interpretacji terminu „wybudowanie” w rozumieniu art. 10 ust. 1 pkt 8 u.p.d.o.f. nie należy odwoływać się do instytucji prawa budowlanego. W szczególności, nie jest konieczne uzyskanie pozwolenia na używanie budynku czy fakt zawiadomienia organu nadzoru budowlanego o zakończeniu budowy. Wykładni terminu „wybudowanie" dokonywać należy jedynie w oparciu o znaczenie, jakie

10 Wyrok NSA z 28.01.1998 r., I SA/Gd 208/96.

11 Wyrok NSA z 9.04.2002 r., III SA 2717/2000.

12 Por. J. Bałuta-Szostak, B. Bogdański, Nieruchomości: sprzedaż, najem, dzierżawa - skutki $w$ PIT, CIT i VAT, Warszawa 2009, s. 21. 
nadaje temu słowu słownik języka polskiego. W języku polskim słowo „wybudować” oznacza natomiast tyle, co wznieść jakiś obiekt, postawić jakąś budowlę. Zatem momentem wybudowania jest wzniesienie budynku w takim stanie, by nadawał się do zamieszkania lub w przypadku budynku użytkowego - do użytkowania w innym celu ${ }^{13}$.

Dość często stosowaną przez podatników praktyką zmierzającą do uniknięcia wykonania ciążącego na nich zobowiązania podatkowego $z$ tytułu odpłatnego zbycia nieruchomości było zawieranie umów przedwstępnych sprzedaży, opiewających na 100\% wartości transakcji. Obejście przepisów prawa podatkowego polegać miało w tym przypadku na tym, że strony takiej umowy odraczały moment zawarcia umowy przyrzeczonej (właściwej umowy sprzedaży nieruchomości) do czasu, aż upłynie pięcioletni okres, licząc od końca roku, w którym nastąpiło zawarcie umowy przedwstępnej. Co więcej, już w momencie zawierania umowy przedwstępnej strony zastrzegały, że oprócz „zaliczki” wypłacanej przez nabywcę na poczet przyszłej ceny sprzedaży, która notabene wynosiła $z$ reguły $100 \%$ wartości transakcji, przyszły zbywca od razu zobowiązany był wydać nieruchomość nabywcy. Pomijając fakt, że transakcja taka jest niezmiernie niekorzystna i ryzykowana dla przyszłego nabywcy, który mimo dokonania zapłaty ceny nie staje się w ciągu kilku następnych lat właścicielem nieruchomości ze wszystkimi wynikającymi $z$ tego faktu konsekwencjami w sferze prawa cywilnego, ten sposób unikania opodatkowania transakcji uznać należy za daleko nieskuteczny i bardzo łatwy do zakwestionowania przez organy podatkowe.

Po pierwsze zasadne jest powołanie się tutaj na okoliczność pozorności czynności prawnej pomiędzy stronami umowy przedwstępnej. Zgodnie $z$ brzmieniem art. 199 a § 2 Ordynacji podatkowej $^{14}$, jeżeli pod pozorem dokonania czynności prawnej dokonano innej czynności prawnej, skutki podatkowe wywodzi się z tej ukrytej czynności prawnej. W tym wypadku z punktu widzenia jej skut-

13 Wyrok NSA z 19.05.2000 r., I SA/Lu 238/99, niepubl.

14 Ustawa $z$ dnia 29 sierpnia 1997 roku Ordynacja podatkowa (Dz.U. z 2005 r. Nr 8, poz. 60 ze zm.). 
ków w zakresie prawa podatkowego umowa przedwstępna traktowana byłaby jako umowa przyrzeczona. Należy jednak pamiętać, że ten sposób wyeliminowania możliwości obejścia prawa jest skuteczny, aczkolwiek dość czasochłonny, ponieważ organy podatkowe nie są władne oceniać, czy dana czynność prawna ma cechy pozorności, co implikuje konieczność uprzedniego uzyskania orzeczenia sądu cywilnego w tym przedmiocie.

Inną metodą zakwestionowania legalności praktyk, o których mowa, jest sama dogłębna analiza konstrukcji oraz celu umów przedwstępnych. Umową przedwstępną (pactum de contrahendo) uregulowaną w przepisie art. 389 k.c. jest taka umowa, przez którą jedna ze stron lub obie zobowiązują się do zawarcia oznaczonej umowy zwanej umową przyrzeczoną. Umowę przedwstępną zawiera się wtedy, gdy niezwłoczne zawarcie umowy definitywnej nie jest $\mathrm{w}$ danym momencie możliwe lub jest dla stron $\mathrm{z}$ jakichkolwiek powodów niedogodne. Od innego rodzaju umów odróżnia ją więc przede wszystkim szczególna jej treść, którą stanowi zobowiązanie się do zawarcia innej umowy w przyszłości. Innymi słowy, świadczeniem wynikającym $z$ umowy przedwstępnej jest zawarcie umowy definitywnej ${ }^{15}$.

Kwestią doniosłą w kontekście omawianej problematyki jest wskazanie podstawowych różnic pomiędzy umową przedwstępną a umową definitywną zawartą pod warunkiem lub z zastrzeżeniem terminu. Otóż umowa przedwstępna charakteryzuje się tym właśnie, że jest ona zawsze tylko i wyłącznie zobowiązaniem do zawarcia przyszłej umowy przyrzeczonej. Zatem na podstawie samej umowy przedwstępnej nie można żądać spełnienia tych świadczeń, do których strony mogą zobowiązać się dopiero w będącej jej realizacją umowie definitywnej. Takie stanowisko potwierdził Sąd Najwyższy, stwierdzając, że zastrzeżone w umowie przedwstępnej świadczenie strony na poczet umowy przyrzeczonej nie czyni drugiej strony uprawnioną do żądania spełnienia tego świadczenia ${ }^{16}$. Dopiero bowiem ta druga, przyszła umowa przyrzeczona w sposób

15 Zob. Z. Radwański, A. Olejniczak, Zobowiązania: część ogólna, Warszawa 2008, s. 138.

16 Wyrok SN z 22.12.2000 r., II CKN 353/00. 
kompleksowy reguluje prawa i obowiązki stron wynikające $z$ zamierzonego przez nie celu gospodarczego. W razie wątpliwości, czy strony zawierają umowę przedwstępną, czy definitywną, jak wskazuje $Z$. Radwański, wyjść trzeba $z$ założenia, że strony $z$ reguły dążą do bezpośredniego zrealizowania zamierzonego celu gospodarczego. Tak więc, w sytuacji gdy spełnione zostaną wszystkie przesłanki konieczne do zawarcia umowy definitywnej, przyjąć należy, że mamy do czynienia $z$ umową definitywną, a nie przedwstępną. Stanowisko takie już dawno zyskało pełną aprobatę w judykaturze ${ }^{17}$.

\section{Zasady dotyczące opodatkowania odpłatnego zbycia nieruchomości}

W art. 7 ust. 1 ustawy $z$ dnia 16 listopada 2006 r. o zmianie ustawy o podatku dochodowym od osób fizycznych oraz zmianie niektórych innych ustaw ${ }^{18}$ czytamy, że do przychodu (dochodu) $z$ odpłatnego zbycia nieruchomości i innych praw majątkowych, nabytych lub wybudowanych do dnia 31 grudnia 2006 r., stosuje się zasady w brzmieniu obowiązującym przed dniem 1 stycznia 2007 r. Z uwagi na powyższe o reżimie podatkowym, jakiemu podlegać będzie transakcja odpłatnego zbycia, przesądzać będzie więc moment nabycia lub wybudowania nieruchomości. $Z$ tego względu konieczne staje się przedstawienie zasad opodatkowania odnoszących się do przychodów uzyskiwanych ze sprzedaży nieruchomości według stanu prawnego sprzed dnia 1 stycznia 2007 r.

\section{A. Stan prawny obowiązujący przed dniem 1 stycznia 2007 r.}

Do końca roku 2006 opodatkowaniu podlegał przychód uzyskiwany przez podatnika w wyniku dokonywanych przez niego transakcji sprzedaży. Artykuł 19 u.p.d.o.f. wprowadza natomiast definicję szczególną przychodu $z$ odpłatnego zbycia rzeczy i praw

17 Por. uchwałę SN z 26.10.1984 r., III CZP 64/84.

18 Dz.U. z 2006 r. Nr 217, poz. 1588. 
majątkowych, będącą $\mathrm{w}$ istocie rzeczy lex specialis $\mathrm{w}$ stosunku do ogólnej definicji przychodu zawartej w art. 11 ust. 1 ustawy. W przepisie art. 19 u.p.d.o.f. czytamy mianowicie, że przychodem $z$ odpłatnego zbycia nieruchomości i innych praw majątkowych, o których mowa w art. 10 ust. 1 pkt 8, jest ich wartość wyrażona w cenie określonej w umowie, pomniejszona o koszty odpłatnego zbycia. W przypadku sprzedaży nieruchomości wyłączony jest więc ogólny wymóg faktu otrzymania lub pozostawienia do dyspozycji podatnika pieniędzy i wartości pieniężnych, o którym mowa w art. 11 ust. 1 u.p.d.o.f.

A zatem w świetle brzmienia przepisu art. 19 u.p.d.o.f. przychód uzyskany przez podatnika w wyniku sprzedaży nieruchomości rozlicza się $\mathrm{w}$ wyniku zastosowania metody memoriałowej, a nie jak to jest w większości przypadków - metody kasowej. Innymi słowy, opodatkowaniu podlega przychód należny, bez względu na to, czy został on faktycznie otrzymany przez podatnika. Dla powstania przychodu po stronie podmiotu dokonującego transakcji zbycia jest więc kwestią prawnie indyferentną ta okoliczność, czy sprzedający faktycznie uzyskał cenę lub inne świadczenie od nabywcy. Zasadniczą konsekwencją tego stanu rzeczy jest to właśnie, że dla wystąpienia skutków podatkowoprawnych wystarczająca jest sama okoliczność zawarcia umowy sprzedaży, w której kontrahenci ustalili wartość zbywanej nieruchomości. Powyższa teza współcześnie jest całkowicie akceptowana w orzecznictwie i doktrynie. Na przykład w orzeczeniu z 28 czerwca 2000 r. Naczelny Sąd Administracyjny stwierdził, że „bez znaczenia dla celów podatkowych jest ta okoliczność, czy cena została zapłacona, bowiem obowiązek podatkowy powstaje w dacie zawarcia umowy"19.

W tym miejscu warto również wspomnieć, że wartość wyrażona w cenie zawsze będzie stanowić przychód, i to bez względu na to, w jakiej formie cena została zapłacona. Może ona w szczególności przybrać formę zwolnienia $z$ długu ${ }^{20}$ czy też przedstawienia do potrącenia wymagalnych wierzytelności.

19 Wyrok NSA z 28.06.2000 r., SA/Gd 2258/95.

20 Zob. wyrok NSA z 18.05.1999 r., III S.A. 7/98. 
Kosztami odpłatnego zbycia są natomiast koszty związane z samym zawarciem i dojściem do skutku umowy przenoszącej własność nieruchomości. Judykatura wymienia wśród nich m.in. opłaty związane $z$ wyceną rzeczoznawcy, prowizję pośrednika handlu nieruchomościami, taksę notarialną, opłaty sądowe, koszty zamieszczonych ogłoszeń w prasie o zamiarze dokonania sprzedaży, a także koszty poniesione $\mathrm{w}$ związku $\mathrm{z}$ przystosowaniem lokalu do użytkowania go zgodnie $z$ zamiarem przyszłego nabywcy.

Opodatkowanie wyłącznie przychodu, a nie dochodu $z$ odpłatnego zbycia oznacza, że prawnie indyferentna jest dla podatnika kwestia poniesienia kosztów uzyskania przychodu. Podatnik nie ma więc prawnie dopuszczalnej możliwości pomniejszenia przychodu o ewentualnie poniesione koszty jego uzyskania.

Wartość nieruchomości będącej przedmiotem transakcji zbycia ustalać należy przy zastosowaniu cen rynkowych stosowanych $\mathrm{w}$ obrocie rzeczami i prawami tego samego rodzaju i gatunku, z uwzględnieniem w szczególności ich stanu i stopnia zużycia oraz czasu i miejsca odpłatnego zbycia ${ }^{21}$. Należy mieć jednak na uwadze, że od tej ogólnej zasady ustawa przewiduje pewne odstępstwa. I tak - jak czytamy w art. 19 ust. 1 zdanie 2 u.p.d.o.f. - jeżeli cena bez uzasadnionej przyczyny znacznie odbiega od wartości rynkowej tych rzeczy i praw, przychód określa organ podatkowy lub organ kontroli skarbowej. $Z$ powyższego wynika, że cena ustalona przez strony w umowie może nie pokrywać się z ceną rynkową w dwóch, alternatywnie występujących sytuacjach.

Po pierwsze cena ustalona przez strony może zawsze odbiegać od wartości rynkowej nieruchomości, pod warunkiem, że nie różni się ona od niej w sposób znaczny. Ustawa nie precyzuje jednak, co należy rozumieć pod „znacznie odbiegać”. W związku z tym ustalenia zakresu znaczeniowego tego nieostrego sformułowania dokonano w orzecznictwie oraz doktrynie. I tak w świetle wyroku Naczelnego Sądu Administracyjnego z 12 lutego 1999 r. ${ }^{22}$ nie można uznać ceny umownej odbiegającej o 14\% od rzeczywistej wartości rynkowej za cenę odbiegającą od niej w sposób znaczny. Przyjmuje się

\footnotetext{
21 Art. 19 ust. 3 u.p.d.o.f.

22 Wyrok NSA z 12.02.1999 r., I SA/Lu 943/98.
} 
natomiast, że ceną odbiegającą w sposób znaczny od wartości rynkowej jest cena od niej niższa o $33 \%^{23}$.

Po drugie cena ustalona przez strony w umowie będzie mogła różnić się, i to nawet w sposób znaczny, od rzeczywistej ceny rynkowej wówczas, gdy zaistnieje po temu uzasadniona przyczyna. Również w tym wypadku ustawodawca nie precyzuje, o jaką przyczynę chodzi. W praktyce najczęściej będą nią istniejące między stronami więzi pokrewieństwa.

W sytuacji gdy cena ustalona w umowie znacznie odbiega od wartości rynkowej nieruchomości i odbiega od niej bez uzasadnionej przyczyny, organ władny jest jest wezwać strony do złożenia stosownych wyjaśnień. Jak bowiem podkreśla się w orzecznictwie, nie może on samowolnie określić wartości nieruchomości w oparciu o istniejące ceny rynkowe, jeżeli uprzednio zaniecha wezwania stron do złożenia wyjaśnień w tym przedmiocie ${ }^{24}$. Wezwanie do złożenia wyjaśnień jest warunkiem niezbędnym do ewentualnego skorygowania ustalonej przez nie ceny umownej. Podanie przez strony racjonalnych powodów, dla których cena zawarta w umowie różni się od wartości rynkowej nieruchomości, uniemożliwia ustalenie przez organ podstawy opodatkowania według wyższych cen rynkowych. Chociaż oceny racjonalności przesłanek uzasadniających zróżnicowanie ceny ustalonej w umowie w stosunku do wartości rynkowej sprzedawanej nieruchomości zawsze dokonuje organ podatkowy, to nie ma on w tym zakresie pełnej dowolności.

Osiągnięty $z$ tytułu sprzedaży nieruchomości przychód pomniejszony o koszty odpłatnego zbycia do dnia 1 stycznia 2007 r. opodatkowany był stałą, 10-procentową stawką podatkową. Ponadto przychodów uzyskanych $z$ tytułu odpłatnego zbycia nie łączy się z pozostałymi ewentualnie przychodami podatnika $z$ innych źródeł. Podatnik jest zobowiązany do samoobliczenia tak określonego podatku oraz do jego zapłaty bez wezwania na rachunek urzędu skarbowego właściwego według miejsca zamieszkania podatnika w terminie $14 \mathrm{dni}$ od dnia zawarcia umowy sprzedaży nieruchomości.

23 J. Marciniuk, A. Dąbrowski i inni (red.), Podatek dochodowy od osób fizycznych: 2009, Warszawa 2009, s. 267.

24 Zob. wyrok NSA z 24.02.1995 r., III SA 767/94. 


\section{B. Stan prawny po dniu 1 stycznia 2007 r.}

Całkowicie odmiennie regulują kwestię opodatkowania odpłatnego zbycia nieruchomości przepisy, które zaczęły obowiązywać, począwszy od 1 stycznia 2007 r. Odnoszą się one do tych wszystkich transakcji, w których przedmiotem sprzedaży były nieruchomości nabyte lub wybudowane po tej dacie.

Przede wszystkim należy zwrócić uwagę, że opodatkowaniu podlega już nie przychód, lecz dochód osiągnięty przez podatnika. W przepisie art. 30e ust. 1 u.p.d.o.f. czytamy, że od dochodu z odpłatnego zbycia nieruchomości i innych praw majątkowych podatek wynosi $19 \%$ podstawy obliczenia podatku. Zgodnie zaś $z$ brzmieniem ust. 2 powołanego artykułu podstawą obliczenia podatku $z$ tego tytułu jest dochód stanowiący różnicę pomiędzy przychodem $z$ odpłatnego zbycia a kosztami jego uzyskania, powiększoną o sumę odpisów amortyzacyjnych dokonanych od zbywanych nieruchomości.

Podstawową zmianą, jaką wprowadzono, począwszy od 2007 r., jest więc możliwość uwzględnienia przy obliczaniu podstawy opodatkowania ewentualnie poniesionych przez podatnika kosztów uzyskania przychodów. Zmianę tę należy uznać za wysoce korzystną. Trzeba bowiem podkreślić, że bardzo istotną cechą podatku dochodowego jest prawo podatnika do zmniejszenia podstawy opodatkowania o poniesione przez niego koszty uzyskania przychodów i możliwości skorzystania $z$ tego prawa podatnik nie powinien być przez ustawodawcę pozbawiony.

Katalog kosztów uzyskania przychodów z tytułu odpłatnego zbycia nieruchomości został w sposób wyczerpujący określony w art. 22 ust. 6 c i 6 d u.p.d.o.f. Ze wspomnianych przepisów dowiadujemy się, że są nimi:

a) w przypadku odpłatnego zbycia nieruchomości nabytej odpłatnie - udokumentowane koszty nabycia oraz udokumentowane koszty wytworzenia, powiększone o udokumentowane nakłady, które zwiększyły wartość nieruchomości w czasie jej posiadania,

b) w przypadku sprzedaży nieruchomości nabytej w drodze spadku, darowizny oraz w inny nieodpłatny sposób - udoku- 
mentowane nakłady, które zwiększyły wartość nieruchomości poczynione w czasie jej posiadania, a także kwota zapłaconego podatku od spadków i darowizn przypadającego na sprzedawaną nieruchomość.

Warto w tym miejscu wspomnieć, że koszty nabycia i wytworzenia podlegają corocznej waloryzacji, począwszy od roku następującego po roku, w którym nastąpiło nabycie lub wytworzenie zbywanej nieruchomości, aż do roku poprzedzającego rok podatkowy, w którym nastąpiło ich zbycie. Waloryzacja dokonywana jest w stopniu odpowiadającym wskaźnikowi wzrostu cen towarów i usług konsumpcyjnych, który ogłaszany jest przez prezesa GUS ${ }^{25}$.

\section{Zwolnienia od podatku}

Przychody (dochody) uzyskiwane $z$ tytułu sprzedaży nieruchomości podlegają dość licznym i znajdującym szerokie zastosowanie zwolnieniom podatkowym. Dla nieruchomości nabytych przed 1 stycznia 2007 zwalnia się od podatku:

- przychody uzyskane $z$ tytułu sprzedaży całości lub części nieruchomości wchodzących w skład gospodarstwa rolnego, z wyjątkiem sprzedaży gruntów, które w związku z tą sprzedażą utraciły charakter rolny lub leśny (art. 21 ust. 1 pkt 28 u.p.d.o.f.),

- co do zasady przychody uzyskane $z$ tytułu odszkodowania wypłacanego na podstawie przepisów o gospodarce nieruchomościami, przychody $z$ tytułu odpłatnego zbycia na cele uzasadniające wywłaszczenie nieruchomości oraz $z$ tytułu sprzedaży nieruchomości w związku $z$ realizacją przez nabywcę prawa pierwokupu (art. 21 ust. 1 pkt 29 u.p.d.o.f.),

- przychody z tytułu sprzedaży nieruchomości w zamian za mienie pozostawione za granicą (art. 21 ust. 1 pkt 30 u.p.d.o.f.),

- przychody z tytułu realizacji prawa do rekompensaty oraz sprzedaży nieruchomości lub prawa użytkowania wieczystego nabyte $w$ związku $z$ realizacją prawa do rekompensaty $z$ tytułu

25 Art. 22 ust. $6 f$ u.p.d.o.f. 
pozostawienia nieruchomości poza obecnymi granicami RP (art. 21 ust. 1 pkt 30a u.p.d.o.f.),

- przychody ze sprzedaży nieruchomości w części wydatkowanej nie później niż w okresie 2 lat od dnia sprzedaży na określone cele mieszkaniowe (art. 21 ust. 1 pkt 32 lit. a u.p.d.o.f. - tzw. ulga mieszkaniowa),

- przychody ze sprzedaży nieruchomości, jeżeli sprzedaż nastąpiła w celu uzyskania, wzamian za te nieruchomości lub prawa, spółdzielczego lokatorskiego prawa do lokalu albo budynku mieszkalnego lub jego części (art. 21 ust. 1 pkt 32 lit. b u.p.d.o.f.),

- przychody ze sprzedaży nieruchomości, jeżeli nastąpiła ona $\mathrm{w}$ wykonaniu lub w związku $\mathrm{z}$ wielostronną umową o zamianie tych budynków lub praw do lokali (art. 21 ust. 1 pkt 32 lit. c u.p.d.o.f.),

- przychody ze sprzedaży nieruchomości, jeżeli ich nabycie nastąpiło $\mathrm{w}$ drodze spadku lub darowizny (art. 21 ust. 1 pkt 32 lit. d u.p.d.o.f.),

- przychody ze sprzedaży nieruchomości w części wydatkowanej, nie później niż w okresie 2 lat od dnia sprzedaży, na spłatę kredytu lub pożyczki, a także odsetek od kredytu lub pożyczki zaciągniętej na cele mieszkaniowe na terenie Polski (art. 21 ust. 1 pkt 32 lit. e u.p.d.o.f.).

$Z$ uwagi na dużą doniosłość praktyczną poniżej przedstawione zostaną najważniejsze kwestie dotyczące wspomnianej powyżej tzw. ulgi mieszkaniowej, która w polskim porządku prawnym obowiązywała do końca 2006 r. Jej istota polegała na tym, że przychód $z$ odpłatnego zbycia nieruchomości zwolniony był od opodatkowania, jeżeli uzyskane $z$ tytułu sprzedaży środki podatnik $w$ okresie 2 lat od dnia sprzedaży przeznaczył na nabycie na terytorium RP budynku mieszkalnego lub jego części, lokalu mieszkalnego, stanowiącego odrębną nieruchomość, spółdzielczego własnościowego prawa do lokalu mieszkalnego, gruntu albo prawa wieczystego użytkowania gruntu pod budowę budynku mieszkalnego lub na nabycie prawa do domu jednorodzinnego w spółdzielni mieszkaniowej oraz na budowę, rozbudowę oraz remont lub modernizację własnego budynku mieszkalnego lub lokalu mieszkalnego. 
W celu skorzystania $z$ opisanej ulgi podatnik, który dokonał sprzedaży nieruchomości nabytej lub wybudowanej przed dniem 1 stycznia 2007 r., zobowiązany jest złożyć we właściwym urzędzie skarbowym w terminie 14 dni od dnia sprzedaży nieruchomości oświadczenie o przeznaczeniu przychodu ze sprzedaży na wyżej wskazane cele mieszkaniowe. Co warte podkreślenia, niezłożenie takiego oświadczenia w terminie 14 dni od daty sprzedaży nie skutkuje automatycznym pozbawieniem go możliwości skorzystania z prawa do zwolnienia. Jeżeli bowiem w rzeczywistości podatnik w terminie dwuletnim od daty zbycia wyda uzyskane pieniądze na wskazane cele mieszkaniowe, nadal uprawniony jest do uzyskania zwolnienia podatkowego ${ }^{26} . \mathrm{Z}$ analogiczną sytuacją będziemy mieli do czynienia w wypadku, gdy zapłaci on już należny podatek, lecz w ciągu 2 lat od daty sprzedaży zdecyduje się przeznaczyć uzyskany przychód na cele mieszkaniowe. W takiej sytuacji będzie on mógł skutecznie dochodzić zwrotu nienależnie zapłaconego podatku.

$Z$ dniem 1 stycznia 2007 r. ustawodawca zdecydował się na uchylenie opisywanego powyżej zwolnienia, wprowadzając w to miejsce tzw. ulgę meldunkową. Polegała ona na zwolnieniu od opodatkowania przychodów uzyskanych $z$ odpłatnego zbycia:

- budynku mieszkalnego,

- lokalu mieszkalnego stanowiącego odrębną nieruchomość,

- spółdzielczego własnościowego prawa do lokalu,

- prawa do domu jednorodzinnego w spółdzielni mieszkaniowej,

lub udziałów w wyżej wymienionych prawach, jeżeli podatnik był zameldowany w przedmiotowych budynkach lub lokalach na pobyt stały, nie krótszy niż 12 miesięcy przed datą zbycia.

Ulga meldunkowa wzbudzała jednak od początku swojego istnienia bardzo wiele kontrowersji praktycznych. Przede wszystkim panowały rozbieżności co do momentu, od którego należało liczyć okres zameldowania na pobyt stały. Przez długi czas dominowało stanowisko, wedle którego takim momentem najwcześniej może być 1 stycznia 2007 r. jako dzień wejścia w życie przepisów o omawianej uldze. Takie stanowisko w sposób oczywisty godziło w interesy podatników.

26 Wyrok NSA z 13.09.2004 r., SA/Gd 2587/93. 
Z uwagi na liczne rozbieżności odnośnie do zasad funkcjonowania ulgi meldunkowej jak i postulat zniesienia obowiązku meldunkowego w ogóle ustawodawca zdecydował się na likwidację tego zwolnienia podatkowego, począwszy od 1 stycznia 2009 r. Ze względu jednak na obowiązującą zasadę, że dla zastosowania określonego reżimu prawnego dotyczącego opodatkowania decydujące znaczenie ma data nabycia następnie zbywanej nieruchomości, będą z niej mogli w dalszym ciągu korzystać ci podatnicy, którzy nabyli nieruchomość w przedziale czasowym od 1stycznia 2007 do 31 grudnia $2008 \mathrm{r}$.

W miejsce uchylonej ulgi meldunkowej, począwszy od 1 stycznia 2009 r., ustawodawca postanowił powrócić do rozwiązań stosowanych do końca 2006 r., a nawiązujących w istocie rzeczy do ulgi mieszkaniowej. Niemniej jednak zdecydował się jednocześnie na wprowadzenie kilku istotnych modyfikacji w stosunku do przepisów obowiązujących w tamtym okresie. I tak skorzystanie ze zwolnienia podatkowego od dochodów $z$ tytułu odpłatnego zbycia nieruchomości uwarunkowane jest przeznaczeniem uzyskanych wartości nie później niż w okresie dwóch lat od końca roku podatkowego, w którym nastąpiło zbycie, na enumeratywnie określone własne cele mieszkaniowe ${ }^{27}$.

Ponadto kolejną zmianą w stosunku do stanu prawnego obowiązującego do 2007 r. jest umożliwienie skorzystania $z$ ulgi tym podatnikom, którzy dochód $z$ odpłatnego zbycia przeznaczą na zakup nieruchomości nie tylko na terenie RP, lecz także w państwach członkowskich Unii Europejskiej oraz Konfederacji Szwajcarskiej.

Wreszcie ostatnia istotna zmiana dotyczy zakresu omawianego zwolnienia. Począwszy od 2009 r., znajduje ono zastosowanie do tej części dochodu, który odpowiada iloczynowi tego dochodu i udziału wydatków poniesionych na własne cele mieszkaniowe w przychodzie z odpłatnego zbycia nieruchomości ${ }^{28}$.

Podsumowując rozważania dotyczące problematyki opodatkowania odpłatnego zbycia nieruchomości, nie sposób nie zauważyć, że

\footnotetext{
27 Zob. szerzej art. 21 ust. 25 u.p.d.o.f.

28 Art. 121 ust. 1 pkt 131 u.p.d.o.f.
} 
zaprezentowana materia jest poddawana częstym i daleko idącym zmianom. Ustawodawca wciąż poszukuje najlepszej metody opodatkowania wartości uzyskanych $z$ tytułu odpłatnego zbycia poza wykonywaną przez podatnika działalnością gospodarczą. Można więc zasadnie przypuszczać, że przedmiotowa problematyka w dalszym ciągu będzie obiektem prac legislacyjnych ustawodawcy i prawdopodobnie należy spodziewać się w niedługim czasie kolejnych odnoszących się do niej nowelizacji.

\section{SUMMARY}

\section{Taxation of the disposal of a real property besides economic activity under the provisions of the personal income tax}

The issue of taxation of income resulting from the real estate is of high importance not only for the reason of their value. This problematic is also worth to consider on account of the fact, that taxation of disposal of a real property constitutes a separate source of income under Polish law. Furthermore, many provisons regarding aforesaid topic, firstly alloted or amended by the Statute are still binding due to intertemporal regulations. As a result, the problematic of taxation of the disposal of real property is not very plain and easy to understand. In my article firstly I will focus on the issue of the aim of the taxation in question. Then I will move on to present the major pinciples of taxation of the disposal of the a property. Finally, I will concentrate on the issues of tax holidays concerning this matter. The article will cover in more depth all abovementioned remarks.

Keywords: personal income tax, taxation of payable alienation of the real property, income from payable alienation, preliminary contract, housing relief, domicile relief 